\title{
胃粘膜内癌のリンパ節転移と予後
}

\section{北九州市立医療センター外科, 病理*}

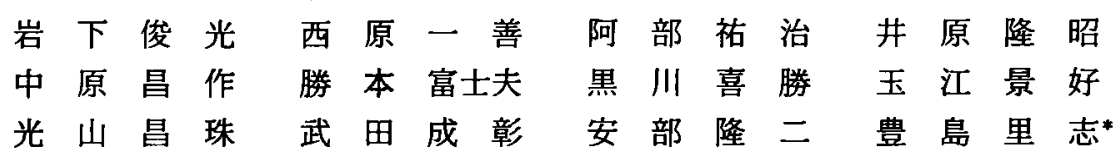

初発単発胃粘膜内癌464例を対象に, リンパ節転移と再発の危険性につき検討した.リ ンパ節転移は 6 例 $(1.3 \%, \mathrm{n} 12$ 例, n2 4 例）にみられ, 腫煌最大径は 1 10 cm（平均 $5.6 \mathrm{~cm}$ )，肉眼型は IIc 3 例, IIc + III 1 例， 3 型 1 例，5 型 1 例と全て潰場合併の楩凹型 で, 組織型は por 3 例, sig 2 例, tub2 1 例で tub2にも一部に低分化腺癌の像があり, 全てに低分化腺癌の部分が見られた。リンパ節転移陽性例は陰性例に比して有意に腫瘍 最大径が大きく潰場合併頻度が高く, 6 例中 3 例が再発死している. 生存例399例と比較 すると癌死例 4 例は腫瘍最大径が全て $4 \mathrm{~cm}$ 以上であり, 溑瘍合併とリンパ節転移陽性の 割合が有意に高かった．潰瘍を伴う陥凹型の低分化腺癌では粘膜内癌でもリンパ節転移 の可能性があり D2のリンパ節郭清が不可欠で,転移があれば術後補助化学療法が必要で ある。

卖引用語：早期胃癌, 胃粘膜内癌, 胃癌リンパ節転移, 胃癌再発

\section{緒 言}

近年, 検診の普及と診断技術の向上により，早期胃 癌症例が增えてきている．当院でも年々早期胃癌は增 加し,最近は,切除胃癌の半数近くを占めるようになっ ている(表 1)。また早期胃癌に対して strip biopsy に よる内視鏡的切除も可能となり一定の適応下に積極的 に行われいー3)，また縮小手術として腹腔鏡下胃局所切 除術 ${ }^{41}$, 開腹胃局所切除術 ${ }^{5 / 28}$, 幽門保存胃切除術 ${ }^{9101}$ な どが報告されている。しかし，早期胃癌でもリンパ節 転移がみられるものや，再発する例も，少数ながら認 められる. 今回は, 特に, 外科的切除胃粘膜内癌のリ ンパ節転移と再発の危険因子について検討した.

\section{表 1 切除胃癌と早期胃雷の年次的变要}

\begin{tabular}{c|c|c|c}
\hline 年代 & 切除胃癌 & 早期胃癌 & 胃粘膜内癌 \\
\hline $1971-1978$ & 917 & $196(21 \%)$ & $90(9.8 \%)$ \\
$1979-1986$ & 870 & $297(34 \%)$ & $138(16 \%)$ \\
$1987-1994$ & 989 & $477(48 \%)$ & $275(28 \%)$ \\
\hline $1971-1994$ & 2,776 & $970(35 \%)$ & $503(18 \%)$ \\
\hline
\end{tabular}

1995年10月20日受付 1996年 5 月17日採用
対象と方法

1971年 1 月から1994年12月までに切除された胃粘膜 内癌503例のうち,残胃癌と多発胃癌を除いた初発単発 胃粘膜内癌464例を対象とし，

1. リンパ節転移陽性例の検討と陽性例との比較

2. 再発癌死例の検討と生存例との比較検討 を行った，検討項目は，年齢，性，部位，肉眼型，腫 瘍最大径, 謴場合併の有無, 肉眼的漿膜浸潤の程度, 組織型, リンパ管侵站, 静脈侵襲, 進行程度, 根治度 である. 2 群間の有意差の検定は $\chi^{2}$ 検定および $\mathrm{t}$ 検定 で行い, 生存率は Kaplan-Meier 法にて算出, 有意差検 定はGeneralized Wilcoxon testにて行い,危険率 $5 \%$ 以下を有意差有りとした。 なお，切除標本病㚆部 は全例 $5 \mathrm{~mm}$ 幅の段階状切片による全割がなされてい る.

\section{成 績}

\section{1. リンパ節転移陽性例の検討と陰性例との比較}

胃粘膜内癌464例中リンパ節転移は 6 例 $(1.3 \%) に$ みられた．その臨床病理学的所見を表 2 に示す．年齢 は38歳から82歳（平均60歳）で, 男性 4 例, 女性 2 例 て, 部位は A 4 例, M 2 例で, 肉眼型は IIc 3 例, IIc + III 1 例, 3 型 1 例, 5 型 1 例で, 全て陥山型で解譬の 
表 2 胃粘膜内癌リンパ節転移陽性症例

\begin{tabular}{|c|c|c|c|c|c|c|c|c|c|}
\hline 症例 & 年此命 & 性 & 部位 & 肉眼型 & $\begin{array}{c}\text { 最大径 } \\
(\mathrm{cm})\end{array}$ & 組織型 & リンパ節檕移 & 满理合併 & 予後 \\
\hline 1 & 38 & M & A & IIc + III & 6.0 & sig & $n 1 \underset{(1 / 10)}{N o 6} 1 / 10$ & $\mathrm{ul}-4$ & 71月蕾死 \\
\hline 2 & 70 & M & $\mathbf{M}$ & 5 & 5.5 & por & n2 $\underset{(1 / 18)}{N \text { No7 }} 1 / 3$ & $\mathrm{ul}-4$ & 61月盘死 \\
\hline 3 & 68 & M & M & 3 & 10 & sig & $\mathrm{n} 2 \underset{(2 / 22)}{\operatorname{No} 7} 1 / 1$ & $\mathrm{ul}-4$ & 27月自殺 \\
\hline 4 & 43 & F & A & IIc & 6.5 & por & n2 $\underset{(12 / 26)}{\operatorname{No} 7} 1 / 5$ & $\mathrm{ul}-2$ & 128月生存 \\
\hline 5 & 82 & F & A & IIc & 4.5 & por & $n 2 \underset{(3 / 13)}{\operatorname{No8}} 1 / 1$ & ul-3 & 25月我死 \\
\hline 6 & 57 & M & A & IIc & 1.0 & tub2 & 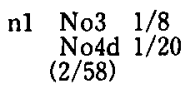 & ul-2 & 73月生存 \\
\hline
\end{tabular}

表 3 胃粘膜内癌： $n(-)$ と $n(+)$ との比較

\begin{tabular}{|c|c|c|c|c|c|c|c|c|c|}
\hline \multirow{2}{*}{ リンパ節転移 } & \multirow{2}{*}{ 最大径 (cm) } & \multicolumn{2}{|c|}{ 謴瘍合併 } & \multicolumn{2}{|c|}{ 槳膜浸潤 } & \multicolumn{2}{|c|}{ 根治度 } & \multicolumn{2}{|c|}{ 生存率 } \\
\hline & & - & + & So & $\mathrm{S} 1 \leqq$ & A & $\mathrm{BC}$ & 5 年 & 10 年 \\
\hline$n(+)$ & $5.6(1-10)$ & 0 & 6 & 4 & 2 & 1 & 5 & $80 \%$ & $34 \%$ \\
\hline $\mathrm{n}(-) \quad 451$ 例 & $3.0(0.1-12)$ & 368 & 82 & 441 & 10 & 441 & 10 & $99 \%$ & $93 \%$ \\
\hline 有意差 & $\mathrm{p}<0.01$ & \multicolumn{2}{|c|}{$\mathrm{p}<0.01$} & \multicolumn{2}{|c|}{$\mathrm{p}<0.01$} & \multicolumn{2}{|c|}{$\mathrm{p}<0.01$} & \multicolumn{2}{|c|}{$\mathrm{p}<0.001$} \\
\hline
\end{tabular}

集中を伴い病巣内に潰瘍または潰瘍瘦痕が認められ た. 腫瘍最大径は $1 \mathrm{~cm}$ から $10 \mathrm{~cm}$ (平均 $5.6 \mathrm{~cm}$ )で, 組 織型は por 3 例, sig 2 例, tub2 1 例で, tub 2 の中に も低分化の部分がみられ，全て癌病巣内に低分化型の 部分を含んでいる.リンパ節転移は $\mathrm{n} 12$ 例， n2 4 例 で，転移個数は 1 個から12個（平均3.5個）であった。

リンパ節転移陽性例と陰性例を比較すると（表 3 ）, 年齢 (平均年齢60歳 vs 59歳), 性, 部位, 肉眼型, 組 織型，リンパ管侵墏，静脈侵襲には差がなかった。リ ンパ節陽性例は陰性例に比して腫場最大径 $(5.6 \mathrm{~cm}$ vs $3.0 \mathrm{~cm})$ が有意 $(\mathrm{p}<0.01)$ k大きく，病巣内漬瘍合併 洺多 $(\mathrm{p}<0.01)$ ，肉眼的獎膜浸潤 $\mathrm{S} 1$ 以上が多 $<(\mathrm{p}<$ $0.01)$ ，根治度 $\mathrm{A}$ が B と C より少なかった $(\mathrm{p}<0.01)$. 予後はりンパ節転移陰性例が有意に $(\mathrm{p}<0.001)$ 良好 で特に 5 年以降の差が大きい（図 1 ).

\section{2. 再発例の検討と生存例との比較}

胃粘膜内癌の再発癌死例は 4 例 $(0.86 \%)$ である (表 4 )。年齢は51歳から82歳 (平均60歳) で, 男 3 例, 女 1 例で，発生部位は A 3 例，M 1 例で, 肉眼型は IIc 2 例 IIc +III I例，5型 1 例で全て陥凹型であった.腫 瘍最大径は $4 \mathrm{~cm}$ から $6 \mathrm{~cm}$ (平均 $5 \mathrm{~cm}$ ) で全て $4 \mathrm{~cm}$ 以上 であった。組織型は sig 2 例, por 2 例と全て低分化型 であった．再発癌死例を生存例と比較すると（表 5 ）,

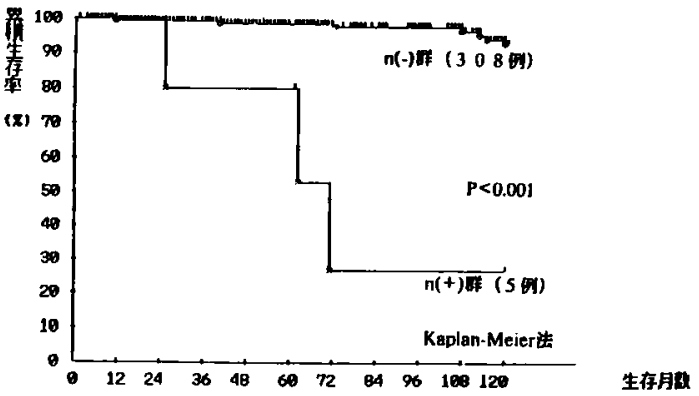

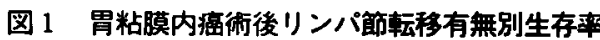
（他病死，他癌死を除く）

年齢（平均年齢60歳 vs 58歳)，性，部位，肉眼型，組

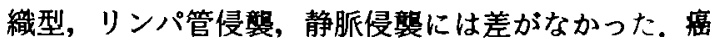
死例は生存例に比して腫場最大径 $(5.0 \mathrm{~cm}$ vs $3.0 \mathrm{~cm})$ が有意に $(\mathrm{p}<0.05)$ 大きく, 癌死例は全て $4 \mathrm{~cm}$ 以上で あった。漬愓合併 $(\mathrm{p}<0.05)$ やリンパ節転移 $(\mathrm{p}<0.01)$ は癌死例に有意に高く, 根治度は癌死例において B と CがAより多かった $(\mathrm{p}<0.01)$.

\section{考 察}

諸家の報告では胃粘膜内癌のリンパ節転移率は $0.6 \%$ 11\% ${ }^{11)-16)}$ て，第63回胃癌研究会アンケート調

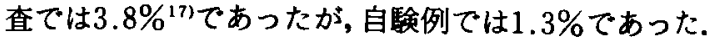


表 4 胃粘膜内症の再発湮死症例

\begin{tabular}{|c|c|c|c|c|c|c|c|c|c|c|c|}
\hline 症例 & 年齢 & 性 & 部位 & 肉眼型 & $\begin{array}{c}\text { 最大径 } \\
(\mathrm{cm})\end{array}$ & 組織型 & リンパ節転移 & 倣清 & 沮瘍 & 生存 & $\begin{array}{l}\text { 再発 } \\
\text { 部位 }\end{array}$ \\
\hline 1 & 51 & $\mathbf{M}$ & A & IIc & 4.0 & sig & $\mathrm{n} 0(0 / 16)$ & D2 & $\mathrm{ul}(-)$ & 112月 & 残胃 \\
\hline 2 & 38 & $\mathbf{M}$ & A & IIc + III & 6.0 & sig & $\mathrm{nl}(1 / 10)$ & D0 & $\mathrm{ul}-4$ & 71月 & 肝門部 \\
\hline 3 & 70 & $\mathbf{M}$ & M & 5 & 5.5 & por & $\mathrm{n} 2(1 / 18)$ & $\mathrm{D} 2$ & $\mathrm{ul} \cdot 4$ & 61月 & 肝門部 \\
\hline 4 & 82 & $\mathrm{~F}$ & A & IIC & 4.5 & por & $\mathrm{n} 2(3 / 13)$ & D1 & ul.3 & 25月 & 骨 \\
\hline
\end{tabular}

表 5 胃粘膜内癌：癌死例と生存例との比較

\begin{tabular}{|c|c|c|c|c|c|c|c|c|}
\hline \multirow{2}{*}{\multicolumn{2}{|c|}{ 予後 }} & \multirow{2}{*}{ 最大径 (cm) } & \multicolumn{2}{|c|}{ 潰㾮合併 } & \multicolumn{2}{|c|}{ リンパ節転移 } & \multicolumn{2}{|c|}{ 根治度 } \\
\hline & & & - & + & $n(-)$ & $n(+)$ & A & $\mathrm{BC}$ \\
\hline 癌死 & 4例 & $5.0(4-6)$ & 1 & 3 & 1 & 3 & 1 & 3 \\
\hline 生存 & 399例 & $3.0(0.1-12)$ & 325 & 74 & 393 & 2 & 389 & 10 \\
\hline \multicolumn{2}{|c|}{ 有意差 } & $p<0.05$ & \multicolumn{2}{|c|}{$p<0.05$} & \multicolumn{2}{|c|}{$p<0.01$} & \multicolumn{2}{|c|}{$p<0.01$} \\
\hline
\end{tabular}

リンパ節陽性例の特徵は㿲壁の集中を伴う陥凹型で 謴瘍または謴瘍痗痕を伴い組織型は低分化型かまたは 一部に低分化型の認められる症例である.岩永ら ${ }^{13)}$ 粘膜内癌でリンパ節転移のあったのは癌病巣内に濽瘍 病変をもった陥凹型であったと報告している，岩下 $ら^{18)}$ はリンパ節転移陽性の粘膜内癌はすべて陥凹型 で，少なくとも一部に低分化型を伴っていると述へて いる．また潰湯を合併しているため進行癌と診断され 肉眼的墏膜浸潤度 S1以上とされた症例が 2 例あった。

腫瘍径との関係では, 主病巣が一定の大きさになる とリンパ節転移率が上昇すると言われている ${ }^{19)}$. 江端 $ら^{201}$ は $2 \mathrm{~cm}$ 以上, 伊藤ら ${ }^{211}$ は $3 \mathrm{~cm}$ 以上, 鈴木ら ${ }^{161}$ は $4 \mathrm{~cm}$ 以上に腫瘍径がなると早期胃癌のリンパ節転移率が高 くなると報告している．自験例では，リンパ節転移陽 性例の腫場最大径は1 $10 \mathrm{~cm}$ (平均 $5.6 \mathrm{~cm}$ ) で, 陰性例 の0.1〜 $12 \mathrm{~cm}$ (平均 $3.0 \mathrm{~cm}$ ) より有意に大きく, 特に4 $\mathrm{cm}$ 以上の症例が有意に多かった。しかし $1 \mathrm{~cm}$ の症例 でも 1 群の 2 カ所にリンパ節転移を認めた。細川ら ${ }^{23)}$ は腫湯径が $4.1 \mathrm{~cm}$ 以上では $4.0 \mathrm{~cm}$ 以下に比へて有意 に再発率が高かったと述べている. 自験例でも $4 \mathrm{~cm}$ 以 上では有意に再発癌死刑が多く, 再発癌死例は全て4 $\mathrm{cm}$ 以上であった。

転移リンパ節は第 1 群 2 例, 第 2 群 4 例であったが, 第 2 群では No. 73 例, No. 81 例に転移が見られ た. 第 1 群に転移がなくて第 2 群にのみ転移があった のは 1例でNo. 7にだけ転移していた。岩永ら ${ }^{13)}$ は合 併潰愓の深いUI-III, U1-IV のものに第 2 群, 第 3 群り ンパ節（No. 12，13，14）などの遠隔部への転移がみ
られたとしているが, 自験例では第 2 群リンパ転移例 はU-II 1 例, U1-III 1 例, Ul-IV 2 例で, 第 1 群リン パ節のみは Ul-II 1 例, Ul-IV 1 例で認められた。 また 岡島ら ${ }^{22}$ は粘膜内癌 63 例中 2 例は第 3 群リンパ節転移 陽性でありすへて No. 12であったと記載しているが, 自験例では第 3 群リンパ節への転移はみられなかった ものの, 2 例にNo. 12のリンパ節再発がみられた. 2 例とも Ul-IV を合併し 1 例はNo. 6 に 1 個, もう 1 例 はNo.7に 1 個転移を諗めるのみであったが，ともに 5 年過ぎて肝門部に再発し死亡していることから手術 時 No. 12のリンパ節に転移していた可能性が考えら れる. 癌発生部位は $\mathrm{A}$ と $\mathrm{M}$ であり, 1 群, 2 群のリン パ節に転移があれば，No. 12のリンパ節の郭清も必要 と考えられる。

リンパ節転移個数は 1 個から 12 個で平均 3.5 個であ るが12個の 1 例以外はすべて 3 個以下であった。しか し12個の症例 (表 2 症例 4) でも D2のリンパ節郭清を 行い UFT3C, PSK 3g, 3 年, UFT2C, PSK 2g 2 年, PSK $2 \mathrm{~g} 1$ 年投与したのち術後 10 年の現在再発の徴候 なく生存中である.またたとえ転移りンパ節が 1 個(表 2 症例 2 )でも D2のリンパ節郭清を行っても抗癌肪を 投与しないと61力月後に再発死している。このような ことからたとえ粘膜内癌といえどもリンパ節転移の risk のある症例では D2以上のリンパ節郭清を行い, リンパ節転移があれば補助化学療法が必要と思われ る. 古河ら ${ }^{24)}$ は胃粘膜内癌のリンパ節転移陽性例の 10 年生存率は $0 \%$ と報告しており, 岩永ら ${ }^{13)}$ もンパ節 転移を認めた早期冒癌は術後再発率が高いので MMC 
などの化学療法の必要性を説いている。

胃粘膜内癌の再発率は第53回胃癌研究会のアンケー

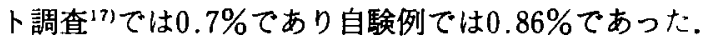
再発例の再発形式はリンパ節転移のない1例では残胃 の再発であり $(1 / 451=0.2 \%)$ ，その他のリンパ節転移 陽性症例 3 例のうち 2 例は肝門部リンパ節再発で， 1 例は全身骨転移であったが，14年前に乳癌にて手術を 受けており乳癌の転移も完全には否定できない. 残胃 再発例は 9 年間は無症状で死亡の 4 力月前に急に経口 摂取不能となっており，残胃の check も必要と思われ る.

\section{結語}

胃粘膜内癌のリンパ節転移と再発の危険因子につい て検討を加えた．再発の危険因子は腫煬径 $4 \mathrm{~cm}$ 以上, 病巣内潰瘍合併, リンパ節転移陽性であり，リンパ節 転移陽性例 6 例中 3 例 $(50 \%)$ が再発している.リン パ節転移の危険因子は腫凚径が大きいこと $(4 \mathrm{~cm}$ 以 上)，病巣内潰瘍の合併，肉眼的墏膜浸潤 S1以上であ り，すべて陥凹型で低分化型か一部に低分化型を有し ていた，潰瘍を伴う陌凹型の低分化型では，胃粘膜内 癌でもリンパ節転移の可能性があり，D2のリンパ節郭 清が必要である. A や M 領域では 1 群，2 群にリンパ 節転移があればNo.12のリンパ節郭清も追加すべき である。リンパ節転移陽性例では術後補助化学療法が 不可欠である.リンパ節転移陰性例でも残胃の check は必要である。

\section{文献}

1）多田正弘, 苅田幹夫, 柳井秀雄他：治療内視鏡法と しての strip biopsyの意義。胃と腸 23：373385,1988

2）竹腰隆男, 藤井 彰, 馬場保昌他：早期胃癌の内視 鏡的切除．消内視鏡 $4: 847-856,1992$

3）鉿木 茂,笹川 㓮, 橋本 洋他：縮小手術とその 成績一早期胃癌に対する内視鏡的治療の成績と評 価一. 外科診療 $34: 33-40,1992$

4）大上正裕, 熊井浩一郎, 若林 剛他：早期胃癌に対 する新しい治療法。 lesion lifting 法による腹腔鏡 下胃局所切除術. 胃と腸 28: 1461-1468, 1993

5）笹子三津留, 木下 平, 丸山圭一地：早期胃癌に対 する局所切除，日消外会誌 $23: 2191-2195,1990$

6）梨本 篤，佐々木寿英： $m, s m$ 早期胃癌に対する 局所治療一外科手術と内視鏡治療の接点一. 日消 外会誌 $26: 2527-2531,1993$

7）高木國夫, 岩切啓二, 武長誠三他：早期周癌に対す る内視鏡的切除を応用した胃局所切除一内視鏡的
治療と縮小手術との接点一、日消外会誌 26 : $2542-2547,1993$

8）田中伸之介, 梅野寿実, 富田昌良他：早期胃溜に対 する縮小手術としての胃局所切除術. 日臨外医会 誌 $56: 1100-1105,1995$

9）中野博重，渡辺明彦，澤田秀智他：胃癌に対する幽 門保存胃切除術の適応と成績. 外科治療 $68: 131$ $-135,1993$

10）佐々木撖, 内藤広郎, 舟山裕士他：幽門保存胃切除 術。臨外 48:161-167, 1993

11）山田栄吉, 紀藤 毅, 鈴木 亮：早期胃癌の予後. 外科 $41: 346-354,1979$

12）高橋俊雄, 河野研一，山口俊晴他：早期胃癌 (A, AM, M 領域癌). 日消外会誌 $16: 123-126,1983$

13）岩永剛, 古河 洋, 多賀一郎他：早期胃癌のリン ハ節転移と予後. 胃癌の診療。外科 Mook, 28, p63 $-70,1982$

14）太田博俊, 高木國夫, 大橋一郎他：早期胃癌1000例 の検討一肉眼分類を中心に一，日消外会誌 14 ： $1399-1408,1981$

15）廣田映五，海上雅光，板橋正幸 他：早期胃癌の病 理. 病理形態と予後。消外 $4: 295-300,1981$

16）鈴木博孝, 遠藤光夫, 鉿木 茂他：早期胃癌におけ るリンパ節転移の検討. 日消外会誌 17：15171526,1984

17）第53回胃癌研究会：早期胃癌治療後再発例に関す ろアンケート集計結果 ( 5 年以内再発例に限る). 日癌治療会誌 $25 ： 1377-1384,1990$

18）岩下明徳, 山田 豊, 有田正秀他：病理学的にみた 早期胃癌内視鏡的切除の適応条件. 胃と腸 26 ： 265-274, 1991

19）武田仁良，掛川暉夫，福嶋博要他：早期胃癌症例の 検討。日臨外医会誌 $43: 667-670,1982$

20）江端俊彰, 南田英俊, 浦 英樹地：臨床病理からみ た早期胃癌の分化型·低分化型胃癌の比較検討. 日 臨外医会誌 $51: 2616-2620,1990$

21）伊藤英人,市倉 隆,玉熊正悦：早期胃癌に対する 合理的リンパ節郭清，早期胃癌のリンパ節転移陽 性例抒よび再発例の検討. 日臨外医会誌 52 : $2566-2572,1991$

22）岡島邦雄：早期胃癌の診断と術後遠隔成䋶。今日 の臨床外科 7, メジカルピュー社, 東京, $1978, \mathrm{p} 105$ $-121$

23）細川 治, 山崎 信, 津田昇志他：早期胃癌切除例 1028例における再発死亡例の検討．臨外 42 ： 1983-1986, 1987 
24）古河 洋, 平塚正弘, 黾山雅男他：早期胃瘦の治療

$86: 1079-1081,1985$

成績からみた外科治療法とその問題点. 日外会誌

\title{
RISK FACTORS OF LYMPH NODE METASTASES AND RECURRENCE FROM INTRAMUCOSAL GASTRIC CANCER
}

\author{
Toshimitsu IWASHITA, Kazuyoshi NISHIHARA, Yuji ABE, Takaaki IHARA, \\ Shosaku NAKAHARA, Fujio KATSUMOTO, Yoshikatsu KUROKAWA, \\ Keiyoshi TAMAE, Shoshu MITSUYAMA, Shigeaki TAKEDA, \\ Ryuji ABE and Satoshi TOYOSHIMA* \\ Department of Surgery and Pathology*, Kitakyusyu Municipal Medical Center
}

Four hundred and sixty-four patients with solitary intramucosal gastric cancer were subjected to a study of risk factors of lymph node metastases and the recurrence. Lymph node metastases were recognized in 6 cases $(1.3 \%, \mathrm{n} 12, \mathrm{n} 24)$. The largest diameters of these tumors ranged from $1 \mathrm{~cm}$ to 10 $\mathrm{cm}$ (mean $5.6 \mathrm{~cm}$ ). They showed macroscopically depressed types including 3 IIc types, IIc + III type, 3 type and 5 type. Histology revealed all the tumors contained foci of poorly differentiated adenocarcinoma including 3 por, 2 sig and tub 2 . Intramucosal gastric cancers with lymph node metastases were characterized by larger diameter, more often associated ulceration and more often overstimated serosal invasion than those without lymph node metastases. Three of 6 patiens with lymph node metastases died of cancer recurrence at 25, 61 and 71 months after surgery. The 4 recurrent cases died of cancer and had larger diameter (more than $4 \mathrm{~cm}$ ) and were more often associated with ulceration and lymph node metastases than nonrecurrent 399 cases. We conclude that the depressed poorly differentiated gastric cancer with ulceration, even if it is an intramucosal cancer, can metastasize to lymph nodes; such a cancer should be treated by gastrectomy with lymph node dissection; and postoperative adjuvant chemotherapy should be mandatory, if lymph node metastases exist. 